\title{
Legal Protection and Legal Defense: Approaches to the Study of Concepts
}

\author{
Anastasia E. Semyonovykh* \\ Ural State Law University, Ekaterinburg, Russia
}

\begin{abstract}
The paper considers a controversial issue of the relationship between the concepts and legal phenomena "legal protection" and "legal defense". The author puts forward and substantiates a hypothesis on the differentiation of the concepts of "legal protection" and "legal defense" based on teleological purposes. Moreover, the author draws attention to the chronological differences in the impact of legal protection and legal defense. The methodology of scientific research includes the dialectical method, as well as general scientific logical operations (deduction and induction, analysis and synthesis) and special scientific methods (formal legal and comparative legal methods). The author studies various epistemological approaches to differentiate concepts and phenomena (study of structure, study of functional purpose, study of instrumental purpose), by the construction of conceptual series. As a result of the research, the author confirms this hypothesis, taking into account the basis of the developed conceptual series.
\end{abstract}

\section{Introduction}

In the theory of law, the issue of understanding "legal protection", its relationship with the concept of "legal defense" at the present stage of development of scientific knowledge remains controversial. For the first time, N.G. Aleksandrov raised the issue of protective relations, suggesting the division of legal norms and legal relations into regulatory and protective [2]. The beginning of theoretical developments regarding legal protection, in the modern sense, was laid by S.S. Alekseev. Studying the functional purpose of law, S.S. Alekseev singled out regulatory and protective functions among the special legal functions of law.

The protective function of law is understood as "the direction of legal influence aimed to protect public relations, their inviolability and, accordingly, the displacement of relations alien to society" [3]. V.N. Protasov equates the identification and development of protective links [14] in the theory of law with scientific discovery, since the presence of such links is not obvious in the mechanism of legal regulation. Their detection is available only with a high level of scientific abstraction and requires a systematic approach. Currently, at the post-non-classical stage of development of science, including the theory of law, we define "legal protection" as one of the elements of legal impact, along with legal institutions, legal management and legal regulation [6].

As for the differentiation of the concepts of legal protection and legal defense, the opinions of researchers on this issue are also ambiguous. For example, some authors identify these concepts, others analyze the difference between these categories and make distinctions on various grounds, correlate these concepts in terms of their volume, defining them as a part and a whole $[12,19]$.

According to the author, these concepts should not be equated, since the main purpose of legal protection is the preventive legal impact [4] on public relations, the prevention of illegal behavior. The purpose of legal defense means is to restore the violated right after its violation.

The synonymous use of the terms legal protection and legal defense leads to the confusion in the conceptual apparatus of the theory of law and identification in legal acts.

The topic of the research is relevant taking into account the importance of protective ties that ensure the normal functioning of the legal system of society and state, the preservation of public relations, the prevention of illegal behavior and the restoration of violated rights.

This paper presents a system of approaches to the study of the concepts of legal protection and legal defense. The author makes an attempt to differentiate these concepts.

\section{Materials and methods}

The methodology of scientific research includes the dialectical method, as well as general scientific logical operations (deduction and induction, analysis and synthesis), and special scientific methods (formal legal and comparative legal methods).

For a systematic study of the legal phenomena of protection and defense within the framework of the methodology of post-nonclassical scientific rationality, the following approaches are used: the study of the

\footnotetext{
Corresponding author: anastasiya.semenovikh@gmail.com
} 
structure, functional and instrumental aspects of legal protection and legal defense.

The method of the construction of conceptual series is used in order to study individual aspects of legal phenomena (structure, functions and instrumentation).

\section{Results and Discussion}

As it is mentioned above, we associate legal protection primarily with the prevention of undesirable and illegal behavior of subjects in society. In the continental legal system, prevention is achieved, first of all, by legal means: the normative consolidation of prohibitions, the availability of powers of state authorities to prevent offenses (for example, a prosecutor's investigation, a prosecutor's warning), the application of various restrictive measures, etc.

As for the Anglo-Saxon legal system, the scientific literature deals mainly with criminal prevention. It is of interest that non-legal methods of crime prevention are more widespread in the common law system.

The authors of one of the concepts of crime prevention distinguish three types of prevention: developmental prevention, community prevention and situational prevention. The prevention of development (evolutionary prevention) includes interventions designed to prevent the development of criminal potential in individuals (for example, children and adolescents from disadvantaged families). Social prevention includes interventions aimed to change social conditions and institutions (for example, families, peers, social norms and organizations) that affect delinquency in particular communities. Situational prevention includes interventions aimed to prevent the occurrence of crimes reducing opportunities and increasing the risk and complexity of the commission of offenses [1].

Thus, we see that, in addition to legal instruments, the mechanism of legal protection in the common law system includes the means developed by other sociohumanitarian sciences, such as sociology, psychology, and pedagogy.

The author proceeds from the following hypothesis: "Legal protection and legal defense are not identical concepts, primarily due to the difference in the purposes of implementation".

Law, as one of the effective means of public administration of society, is always used to implement any social goals: the improvement of the well-being of population, provision of the conditions for active activity of an individual, involvement of everyone in the management of social affairs, provision of public order and state security [18]. In this regard, it is necessary to identify both legal and social goals of legal protection and legal defense.

Legal purpose of protection. The main purpose of legal protection is primarily to prevent violations of the legal norm. The effectiveness of protection increases depending on the observance of the prescriptions of legal norms by the subjects of law and the fulfillment of the requirements of prohibitions. The very fact of the establishment of a ban or a sanction has a serious impact on some people, prompting them to refrain from committing a punishable act [15].

The social goal of protection is to preserve social relations, their fundamental structure, as well as to ensure the stability of the social system in general [6]. For example, in the Federal Law of 10.01.2002 N 7-FL (as amended on July 26, 2019) "On environmental protection", the social goal is defined as meeting the needs of present and future generations, strengthening the legal norm in the field of environmental protection and environmental safety.

As for legal defense, the moment of implementation of legal defense occurs only when the subjective right has already been violated, an offense has been committed. Defense comes into effect when the violation of rights and interests has already occurred [9].

The implementation of legal defense is performed either by special state bodies, for example, a court, or is carried out by the subject of law independently. Thus, the legal purpose of defense is to restore the violated subjective right and bring an offender to justice. The general social purpose of protection is to bring public relations to the state in which they were before the offense. Moreover the purpose is to compensate for the caused harm if it is impossible to restore such a state. Thus, the purpose of legal defense is to restore social justice.

Thus, we confirm the hypothesis about the discrepancy between the concepts of legal protection and legal defense on a teleological basis. Therefore, based on the intended purpose, legal protection and legal defense are different concepts, and protection and defense, as legal phenomena, pursue different purposes - the prevention of offenses and the restoration of violated rights, respectively.

Further, the author dwells on three approaches, with the help of which the author analyzes the concepts and legal phenomena of "protection" and "defense": structural, functional and instrumental. For a deeper and more comprehensive analysis, the author uses the method of the construction of conceptual series, just based on these approaches. The principles of the construction of conceptual series are clearly illustrated by A.M. Vasiliev in his work "Legal categories. Methodological aspects of the development of a system of categories of the theory of law" [5].

The author accepts the concepts of "legal protection" and "legal defense" as the key categories, from which it is necessary to start during the development of a conceptual series. The author builds conceptual series that characterize the structure of phenomena, functional purpose of phenomena and instrumental purpose of phenomena for each of the categories.

The author defines the main elements that describe the structure of the category of legal protection:

- Legal norm;

- $\quad$ Protective legal relationship;

- $\quad$ Object of protective legal relationship;

- Subject of protective legal relationship;

- Content of the protective legal relationship;

- Form of implementation of law. 
In the structural composition of legal defense this legal category is different:

- Legal norm;

- Disputed legal relationship (arising in connection with the existence of a tort, offense or dispute);

- Object of the disputed legal relationship;

- $\quad$ Subject of the disputed legal relationship;

- Content of the disputed legal relationship;

- Form of implementation of law.

This difference is justified by the teleological purpose of legal protection and legal defense, as well as by the moment of the implementation (beginning of action) of these legal phenomena. A lever that triggers a protective legal effect is the very existence of a legal norm prohibiting certain acts of the subject of law. For legal defense, it is necessary to have an act that violates the establishment of a legal norm.

It is necessary to note that the content of each concept in the conceptual series of these two categories can also be different. If the object in protective and controversial legal relations may coincide, for example, a person's life in Article 105 of the Criminal Code of the Russian Federation. The object is the same during the establishment of a protective legal norm and commitment a crime under Article 105 of the Criminal Code of the Russian Federation. However, the subject composition, the content of legal relations and the forms of implementation of subjective rights and legal obligations are different.

The author turns to the next approach and builds conceptual series that characterize the functional purpose of the categories legal protection and legal defense.

According to the functional purpose, both legal protection and legal defense should be attributed to the protective function of law. Sub-functions are often distinguished in the protective function. Based on the hypothesis of the author, these functions must be differentiated between legal protection and legal defense, respectively. The criterion for such a distinction will be the moment of committing an offense, objectively illegal act or abuse of law.

For example, I.F. Kazmin distinguishes five protective subfunctions (preventive, control, conflict, restorative, punitive) [7]. V.D. Filimonov, considering the protective function of criminal law, distinguishes two types of this function (preventive and restorative) [13].

The interesting fact is that some authors (A. I. Korobeev) defining the concept of Criminal law give it in the following two interpretations: the punishability of socially dangerous acts, the procedure and types of release from criminal liability and (or) from punishment, as well as the grounds and limits for the application of measures of a criminal-legal nature that are not punishment; 2) a system of norms regulating relations arising from the commission of socially dangerous acts in order to protect an individual, society and the state from crime" [8].

Based on these definitions, it is seen that in the first case it is concerned with the protective function of criminal law, preventing the violation of the law by the very fact of establishing a criminal law prohibition, and in the second case, it comes to the protective function, which acts as a result of the commission of a socially dangerous act, in in order to restore the violated right.

A.A. Redko, considering the concepts of Law enforcement policy and Human rights policy [16], recognizes that such legal phenomena as protection and defense of rights are inextricably connected, but not identical, since protection is static and is carried out constantly, and the main function of defense is to restore the violated right.

According to the author, the following functions should be distinguished from the point of view of functional purpose in legal protection and legal defense: proactive function, control and supervisory function, preventive function, conflict function, restorative function, punitive function. Moreover, from the point of view of the functional purpose, the law enforcement function should be attributed to the substantive law and the human rights function to the procedural law.

Legal protection should include proactive function (the measures for legal education taken by authorized entities, raising the level of legal culture and other preventive measures), control and supervisory functions (the implementation by authorized entities of measures to verify compliance with legal norms by supervised and controlled objects and entities) and preventive function (the implementation authorized subjects of measures for the prevention and suppression of offenses).

Legal defense should include conflict (the resolution of legal disputes), restorative (the implementation of protection measures, for example, collection of alimony, wage arrears, compensation for harm) and punitive (the application of legal liability and other enforcement measures) functions.

In our opinion, the protective function of law is a common generic basis for the concepts of legal protection and legal defense, which is the basis for the formation of conceptual series, as for paired legal categories.

The instrumental approach is a significant methodological means of understanding legal phenomena. Following the logic of this research, the author applies the instrumental approach to the study of the phenomena of legal protection and legal defense, as well as constructs conceptual series that characterize the instrumental purpose of legal protection and legal defense.

The essence of the instrumental approach is to present objective law "as a tool (mechanism) for the implementation and reproduction of a given social system, its state in a stable, continuously functioning form in time" [11]. That is, a tool is a mean used to solve certain legal problems or situations. Hence, the central concept of the instrumental approach is legal remedy. In the theory of law, legal means are understood as instruments of legal influence used in order to achieve certain results in the process of the solution of social problems and problems facing society and state [10, 17].

Based on the basic properties of law, the author forms conceptual series characterizing the instrumental purpose of legal protection and legal defense. 
First of all, law is characterized by generally binding normativity. A legal norm is a basic unit, a brick of which the legal system is built. A protective legal norm is the very legal means used for the implementation of legal protection (the very fact of the existence of a protective norm restrains subjects of law from violating it) and legal defense (the sanction of a protective legal norm enshrines the punishment provided for a violation of this legal norm). It is necessary to mention that the law is characterized by formal certainty, expressed, inter alia, in the formal consolidation of the primary methods (means) of legal regulation: permission, obligation, prohibition. For legal protection and legal defense, first of all, the establishment of prohibitions in the disposition of the legal norm is typical.

Law is not just a general set of rules of behavior, but a system of legal norms. The consistency of law is clearly manifested in the relationship between branches of law and legal institutions. Such a property as consistency determines the allocation of the following concept in the conceptual series of categories "legal protection" and "legal defense" and "normative legal act".

The law is distinct in its real applicability. The latter feature is presented as a property of law that predetermines its instrumental value in society, because law, as a value, is always an effective law [11].

Depending on the form of implementation, the further formation of the conceptual series characterizing the instrumental purpose of legal protection and legal defense correlates with the conceptual series characterizing the functional purpose of these phenomena. That is, the ratio function is a legal mean. Thus, legal means of legal protection include means of prevention, control and supervisory means, means of prevention and means of restraint. The means of legal defense include means of restoring rights, means of protection, means of coercion and measures of legal responsibility.

\section{Conclusion}

Legal protection and legal defense are not identical concepts and phenomena, primarily according to their teleological purpose.

The main purpose of legal protection is to preserve legal relations in their normal state and prevent offenses and other unlawful behavior of subjects of law.

The purpose of legal defense is to restore violated rights and social justice.

Legal protection begins to operate at the time of the establishment of a protective legal norm. Legal defense is included at the time of violation of law.

The different elementary composition of the formed conceptual series for the categories "legal protection" and "legal defense" proves the lack of identity of these phenomena. Indeed, there are similar elements, but only because "legal protection" and "legal defense" perform a single protective (and not regulatory) function, but share its subfunctions among themselves.

Concept series characterizing the structure of phenomena:

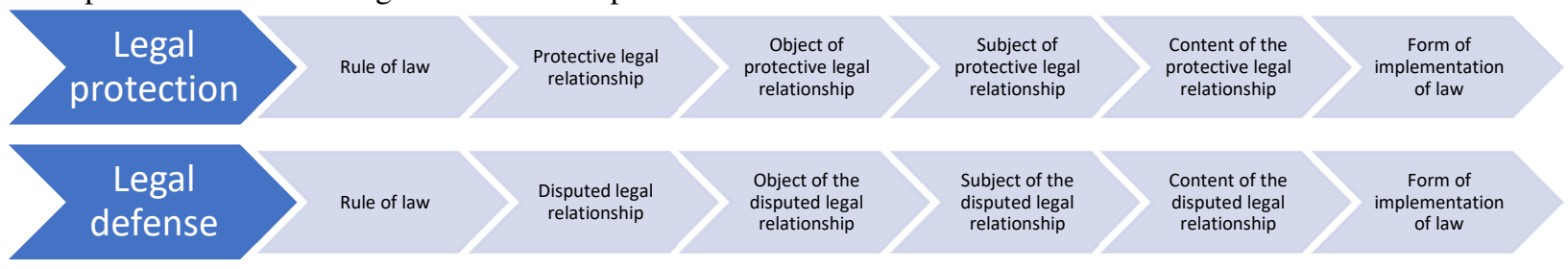

Concept series characterizing the functional purpose of phenomena:

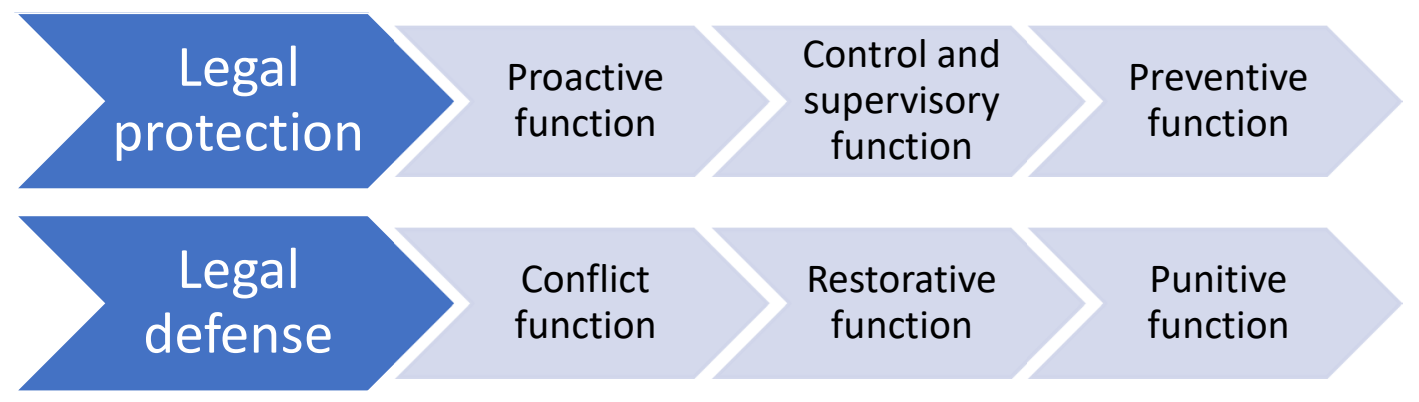

Concept series characterizing the instrumental purpose of phenomena:

\begin{tabular}{|c|c|c|c|c|c|c|c|}
\hline $\begin{array}{l}\text { Legal } \\
\text { protection }\end{array}$ & Legal norm & $\begin{array}{l}\text { Normative } \\
\text { legal act }\end{array}$ & Legal means & $\begin{array}{l}\text { Proactive } \\
\text { means }\end{array}$ & $\begin{array}{l}\text { Control and } \\
\text { supervisory } \\
\text { means }\end{array}$ & $\begin{array}{c}\text { Preventive } \\
\text { means }\end{array}$ & $\begin{array}{l}\text { Means of } \\
\text { restraint }\end{array}$ \\
\hline $\begin{array}{c}\text { Legal } \\
\text { defense }\end{array}$ & Legal norm & $\begin{array}{l}\text { Normative } \\
\text { legal act }\end{array}$ & Legal means & $\begin{array}{l}\text { Restoration } \\
\text { means }\end{array}$ & $\begin{array}{l}\text { Defense } \\
\text { means }\end{array}$ & $\begin{array}{c}\text { Coercive } \\
\text { means }\end{array}$ & $\begin{array}{c}\text { Measures of } \\
\text { legal } \\
\text { responsibility }\end{array}$ \\
\hline
\end{tabular}


The study was financed by the Russian Foundation for Basic Research within the framework of scientific project No. 20311-90054.

\section{References}

1. B. C. Welsh, G. M. Zimmerman, S. N. Zane, The Centrality of Theory in Modern Day Crime Prevention: Developments, Challenges, and Opportunities, Justice Quarterly, 35(1), 139-161 (2018). DOI: $10.1080 / 07418825.2017 .1300312$

2. N.G. Aleksandrov, Legality and legal relations in the Soviet society (Moscow, 1955) pp. 91-92.

3. S.S. Alekseev, Collected Works. In 10 volumes [+ Reference volume]. Volume 3: Problems of the theory of law: A course of lectures (Statut, Moscow, 2010) p. 94.

4. L.N. Berg, Legal protection: the basis of classification, types, Legal science and law enforcement practice, 3, 22-27 (2017)

5. A.M. Vasiliev, Legal categories: methodological aspects of the development of a system of categories of the theory of law: monograph (Norm: INFRA-M, Moscow, 2021) $264 \mathrm{p}$.

6. L.N. Berg, Research of legal impact: methodology, theory, practice: doctoral dissertation

7. I.F. Kazmin, General problems of law in the context of scientific and technological progress (Moscow, 1986) p. 169.

8. I. Ya. Kozachenko, G. P. Novoselov, Criminal law. General part: textbook for universities, $6^{\text {th }}$ ed. (Yurayt Publishing House, Moscow, 2021) 430 p.
9. O.S. Lapshina, Protective function of law in the system of functions of law and state: candidate dissertation (Togliatti, 2011) $180 \mathrm{p}$.

10. A.V. Malko, Legal means as a general theoretical problem, Jurisprudence, 2, 12 (1999)

11. E.F. Mosin, V.A. Sapun, Legal understanding and the instrumental value of law (in the context of the scientific concept of A.V. Polyakov), News of higher educational institutions. Jurisprudence, 5(316), 114-126 (2014)

12. I.A. Kartashkin, N.S. Kolesova, A.M. Larin, I.A. Ledyakh et al., General theory of human rights (Norma, Moscow, 1996) p. 171.

13. V.D. Filimonov, Protective function of criminal law. Theory and practice of criminal law and criminal procedure (Legal Center, 2003)

14. V.N. Protasov, General theory of procedural law: a textbook for universities (Yurayt Publishing House, Moscow, 2021) p. 73.

15. T.N. Radko, Theory of state and law (Unity-Dana, Moscow, 2004) p. 236.

16. A.A. Redko, From law enforcement policy to human rights, Bulletin of the Volgograd Academy of the Ministry of Internal Affairs of Russia, 2(37), 18-23 (2016)

17. V.A. Sapun, Theory of legal means and the mechanism for the implementation of law (SPbGUP, St. Petersburg, 2002) p. 29

18. V.M. Syrykh, History and methodology of legal science: textbook. 2nd ed. (Legal Norm: INFRA-M, Moscow, 2020) $512 \mathrm{p}$.

19. N.I. Matuzov, Legal system and personality (Publishing house of Saratov University, Saratov, 1987) pp. 130-131. 